\title{
Targeting of Bcl-2 family proteins for treatment of acute leukaemia
}

\author{
Jana Jurečeková, Jozef Hatok, Andrea Štefániková, Dušan Dobrota and Peter Račay \\ Department of Medical Biochemistry, Jessenius Faculty of Medicine, Comenius University, Martin, Slovak Republic
}

\begin{abstract}
Many studies suggest that killing of tumour cell by commonly used therapies (chemotherapy, radiotherapy) is mediated primarily by induction of apoptosis. Therefore, resistance of tumour cells to therapy can be caused by a failure in the ability to initiate apoptosis. Defects in apoptosis signalling pathways are also one of the main features of cancer, and particularly acute leukaemia. Malignant cells constantly resist the effects of cellular stress (e.g. DNA damage, oncogene activation), which would cause death of normal cells through apoptosis. Dysregulation of apoptosis has therefore give rise to tumour growth, disease progression and resistance of malignant cells to chemotherapy. Structural analysis of Bcl-2 family proteins playing a key role in regulation of mitochondrial apoptosis together with studies of their biochemical functions have outlines strategies for generation of drugs, resulting in numerous novel chemical entities with potential to reverse resistance of malignant cells to apoptosis. The use of these therapeutic approaches may in the future represent a new way in cancer therapy with high potential to improve clinical outcome and prognosis of acute leukaemia patients.
\end{abstract}

Key words: Apoptosis - Cancer therapy — Leukaemia - Resistance

\section{Introduction}

Apoptosis is physiological, genetically controlled process that leads to a cell death, which is not accompanied by an inflammatory response. It provides fast and effective removal of unwanted, damaged and potentially dangerous cells such as cells infected with viruses and tumour cells in order to maintain tissue homeostasis (Taylor et al. 2006). Induction of apoptosis may be caused by variety of stimuli from external or internal environment of cells. These include genotoxic and physical shock, hypoxia, expression of oncogenes or exposition of cells to cytotoxic drugs used in treatment of cancer (Haupt et al. 2003). Despite the diversity of stimuli that lead to apoptosis, the process of programmed cell death is associated with characteristic morphologic changes, as first described by Kerr et al. (1972). Cell shrinkage, condensation of nuclear chromatin, cleavage of DNA at internucleosomal sites, resulting in the generation of a characteristic pattern of DNA fragments, are typical features of apoptosis (Jin and ElDeiry 2005). Blebbing of the cell surface results in the release

Correspondence to: Jana Jurečeková, Department of Medical Biochemistry, Jessenius Faculty of Medicine, Comenius University, Malá Hora 4, 03601 Martin, Slovak Republic

E-mail: jurecekova@jfmed.uniba.sk of membrane-bound apoptotic bodies, which are recognized by macrophages, or neighbouring cells that consume them, without inflammatory reaction of surrounding tissue. The majority of the morphologic changes during apoptosis are caused by a family of intracellular cysteine proteases, called caspases, involved in the enzymatic cascade entailing the cell death. Caspases are synthesised as inactive zymogens and are proteolytically processed to an active form following apoptotic stimulus (Schultz and Harrington 2003; Jin and ElDeiry 2005). Caspases involved in apoptosis are according to their functions divided into two groups to initiator caspases (caspase 2, 8, 9, 10), which are capable of autocatalytic activation and mediate the activation of second group of effector caspases (caspases 3,6,7), which are capable to cleave many cellular substrates, thereby induce cell death (Testa and Riccioni 2007). Molecular mechanisms of apoptosis, particularly at the level of initiation, are diverse. At present, the extrinsic (receptor) and intrinsic (mitochondrial) pathway are considered as dominant mechanisms of apoptosis (Reed and Pellecchia 2005). The extrinsic pathway is triggered by the binding of an extracellular ligand to a receptor on the plasma membrane, which induces the formation of the death-inducing signalling complex (DISC). Formation of DISC triggers cleavage of procaspase 8 to its active form, which subsequently activates effector caspases, including 
caspase 3 (Haupt et al. 2003; Schultz and Harrington 2003; Elmore 2007). The intrinsic pathway is activated in response to intracellular stress signals (e.g. activation of oncogenes, DNA damage, oxidative stress, disturbances in protein folding) but also to the effects of stimuli from the external environment (e.g. removal of growth factor, ischemia and viral infection) (Elmore 2007). These stimuli lead to the release of cytochrome $c$ from mitochondria into the cytoplasm, due to changes in mitochondrial outer membrane permeability, formation of apoptosome and consequent activation of initiator caspase 9 which in turn activates effector caspase 3 (Chipuk et al. 2008).

\section{Apoptosis and leukaemia}

Deregulation of apoptosis plays an important role in the development of a variety of human pathologies, including autoimmune diseases, neurodegenerative disorders and cancer. It is generally accepted that cancer progression is not the result only of increased rate of cell proliferation but also of decreased rate of cell elimination through apoptosis (Hanahan and Weinberg 2000). Precise identification of the different components of apoptotic pathways allowed the detection of various defects of apoptosis associated with leukaemia (Kitada et al. 2002). These defects provide a survival advantage of leukaemic blasts over their normal counterpart and are frequently associated with worse response to standard chemotherapy and with poor survival of patients (Letai et al. 2004). Since the main goal of anticancer chemotherapy is to induce apoptosis of malignant cells, the failure of apoptosis may also reduce the sensitivity of malignant cells to treatment and cause resistance (Wong and Puthalakath 2008). Identification of the molecular mechanisms of apoptosis deregulation in malignant cells has led to cancer therapies directly targeting the apoptotic pathway. Many of the drugs having potential to restore the sensitivity of leukaemic cells to apoptotic stimuli are currently under investigation at a clinical level (Schuler and Szende 2004).

The effect of chemotherapy may results in activation both mitochondrial and receptor pathway of apoptosis. However, recent analysis of targeted disruption of genes involved in the mitochondrial pathway point to a crucial and indispensable role of mitochondrial pathway of apoptosis in response to anticancer therapy (Testa and Riccioni 2007). Therefore, deregulation of mitochondrial apoptosis in acute leukaemia will be the focus of this review.

\section{Bcl-2 family of proteins}

Proteins of Bcl-2 family that control and affect the permeability of mitochondrial outer membrane are the key regu- lators of mitochondrial apoptosis pathway (Chipuk et al. 2008). The Bcl-2 proteins contains at least one of the four $\mathrm{Bcl}-2$ homology $(\mathrm{BH})$ domains designated $\mathrm{BH} 1, \mathrm{BH} 2, \mathrm{BH} 3$ and $\mathrm{BH} 4$. Proteins, through the $\mathrm{BH}$ domains, specifically affect each other to form homo- and heterodimers, to ensure their pro- or antiapoptotic function (Kim et al. 2006). To date, 25 members of the Bcl-2 family of proteins, located predominantly in the outer mitochondrial membrane, have been identified. Proteins of Bcl-2 family can be divided into three subfamilies based on structural and functional features (Youle and Strasser 2008) (Table 1).

Antiapoptotic proteins (Bcl-2, Bcl-xl, Bcl-w, Al and MCL1) contain all four $\mathrm{BH}$ domains and their main function is to promote cell survival. In the 3-dimensional structure, the $\mathrm{BH}$ domains are arranged to form a hydrophobic groove on the surface of antiapoptotic proteins. Integrity of hydrophobic groove is essential for their antiapoptotic function and for binding to proapoptotic proteins. This fact forms the basis for the development of inhibitors of antiapoptotic Bcl-2 proteins that bind with high affinity into the hydrophobic groove, thus block their antiapoptotic function (van Delft and Huang 2006).

Another group consist of proapoptotic proteins (BAX, $\mathrm{BAK})$ containing three $\mathrm{BH}$ domains $(\mathrm{BH} 1, \mathrm{BH} 2$ and $\mathrm{BH} 3$ ) and are termed "multidomain proteins". In viable cells, the „multidomain“ proapoptotic members are present in the

Table 1. Survey of Bcl-2 family proteins (according to Strasser 2005)

\begin{tabular}{lll}
\hline Protein & Domains & Function \\
\hline Bcl-2 & BH1, BH2, BH3, BH4, TM & \\
Bcl-w & BH1, BH2, BH3, BH4, TM & \\
Bcl-xl & BH1, BH2, BH3, BH4, TM & $\begin{array}{l}\text { Pro-survival/anti-apop- } \\
\text { totic proteins }\end{array}$ \\
A1 & BH1, BH2, BH3, BH4 & \\
BOO & BH1, BH2, BH3, BH4, TM & \\
MCL1 & BH1, BH3, TM & \\
\hline BAX & BH1, BH2, BH3, TM & \\
BOK & BH1, BH2, BH3, TM & Pro-apoptotic \\
BAK & BH1, BH2, BH3, TM & BAX/BAK-like proteins \\
Bcl-xs & BH3, BH4, TM & \\
\hline Bcl-gl & & Pro-apoptotic proteins \\
BFK & & \\
\hline BAD & BH3 & \\
BID & BH3 & \\
BIK & BH3, TM & \\
HRK & BH3, TM & \\
BIM & BH3, TM & Pro-apoptotic BH3-only \\
Noxa & BH3, BH3 & \\
PUMA & BH3 & \\
BMF & BH3 & \\
\hline
\end{tabular}


form of inactive monomers at the mitochondria (BAK), where are bound to antiapoptotic proteins Bcl-xl or MCL1, or in the cytosol (BAX) (Willis et al. 2005; van Delft and Huang 2006). Apoptotic stimuli lead to translocation of BAX to mitochondrial membrane, followed by homooligomerisation of BAX protein. BAK also homooligomerises into multimers and such both proteins form their active conformations. Oligomerised BAX and BAK form pore in mitochondrial membrane and thus facilitate the release of cytochrome $c$ from mitochondria to cytosol, causing the initiation of apoptosis (Youle and Strasser 2008).

The last group consists of proteins containing only $\mathrm{BH} 3$ domain. These proteins are termed "BH-3 only" proteins. They function as primary sensors of apoptotic stimuli arising from various cellular processes. This group includes: BIK, HRK, BIM, BAD, BID, PUMA and Noxa (Wong and Puthalakath 2008). The shape of the BH3 domain of these proteins allows its insertion into the hydrophobic groove of antiapoptotic proteins and such inhibit their function. Therefore, the main task of this group is to promote cell death by formation of heterodimers with antiapoptotic proteins, thereby indirectly activate proapoptotic BAX and/or BAK and release of cytochrome $c$. Some "BH-3 only" proteins (e.g. Bid and Bim) may activate BAX and BAK also directly (Kim et al. 2006).

Ratio between pro- and antiapoptotic proteins of Bcl-2 family determines whether cell survives or dies. Disruption of this balance may cause either over induction or in contrast regression of apoptosis (Kim et al. 2006).

In addition to the regulation of cell cycle and DNA repair, p53 is also a dominant regulator of mitochondrial pathway of apoptosis (Fig. 1). pP53 can initiate apoptosis by transcriptional activation of the expression of proapoptotic proteins of Bcl-2 family (e.g. BAX, BAK, PUMA and Noxa) (Sax and El-Deiry 2003), as well as transcriptional repression of antiapoptotic proteins of Bcl-2 family (Wu et al. 2001). Molecular mechanism of transcription-independent pathway by which p53 activates apoptosis involves the direct binding of p53 to several antiapoptotic proteins of Bcl-2 family (e.g. Bcl-xl); thereby p53 inhibits their antiapoptotic function (Mihara et al. 2003; Chipuk et al. 2004). According to its function in cell death and the maintenance of genome stability, p53 is frequently mutated in solid tumours (Soussi 2007), but in haematological malignancies it is a rare feature (Krug et al. 2002). Although p53 mutations in haematological malignancies are infrequent, they are generally associated with

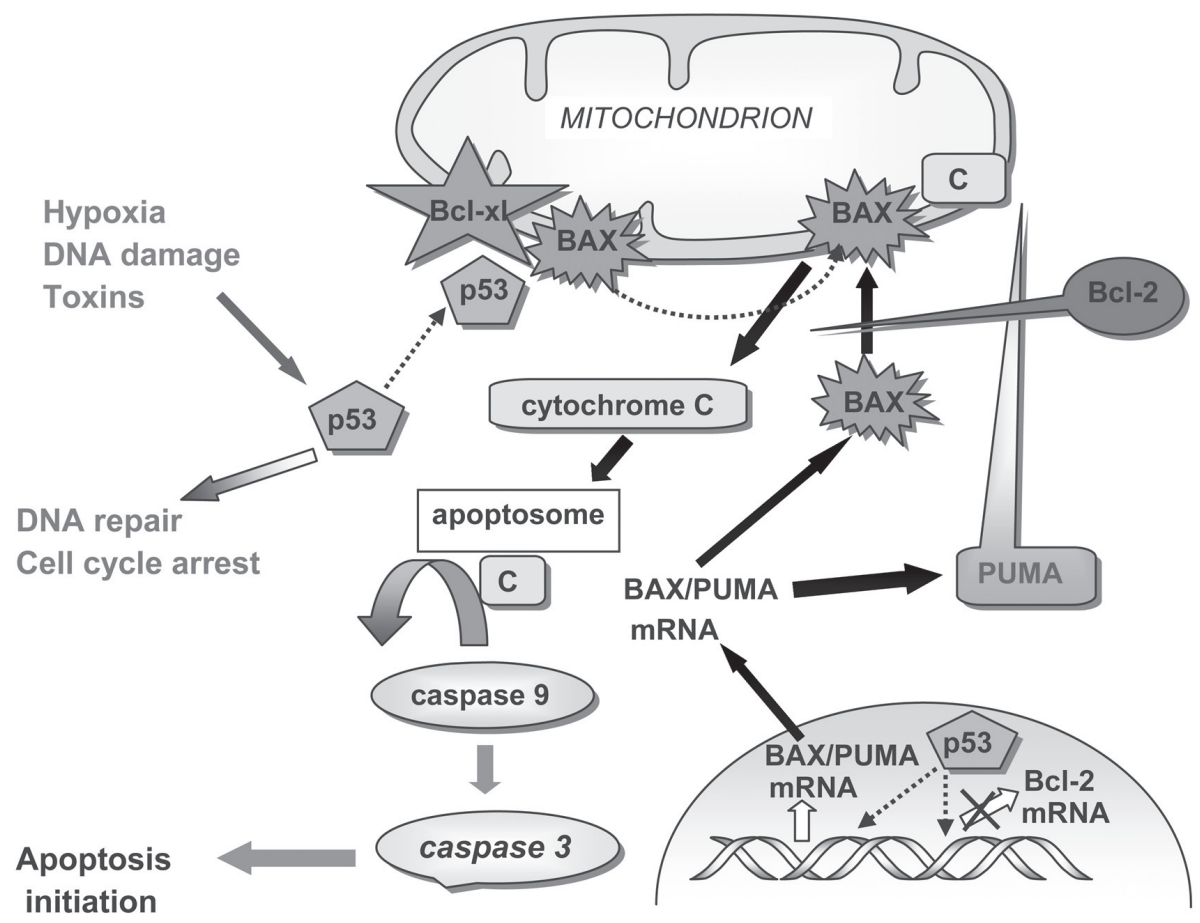

Figure 1. Intrinsic mitochondrial apoptotic pathway (modified according to Polster and Fiskum 2004). Various stressful stimuli, e.g. damage to DNA or hypoxia, stimulate the activation of $\mathrm{p} 53$ by different types of posttranslational modifications. Active p53 induces transcription of several pro-apoptotic genes, including BAX, BID, NOXA, and PUMA as well as represses transcription off anti-apoptotic genes, e.g. Bcl-2. Transcription-independent mechanism involves direct binding of active p53 to anti-apoptotic mitochondrial proteins, e.g. Bcl-xl, inhibiting their ability to block outer membrane pore formation by BAX and BAK. 
worse disease progression and drug resistance (Haferlach et al. 2008; Nahi et al. 2008). Mutations of TP53 gene also contribute to resistance of leukaemic cell lines to irradiation due to delay of induction of apoptosis (Aldridge and Radford 1998; Mareková et al. 2003).

\section{Expression of antiapoptotic Bcl-2 proteins in acute leukaemia}

Increased expression of several antiapoptotic $\mathrm{Bcl}-2$ proteins was observed in various haematological malignancies, including both acute lymphocytic leukaemia (ALL) and acute myelogenous leukaemia (AML). The best studied is expression of Bcl-2 (Klobusicka et al. 2001). High levels of Bcl-2 may occur as a result of the $t(14 ; 18)$ translocation, present in a high percentage of follicular lymphomas (Tsujimoto et al. 1985). This translocation places the $B c l-2$ gene into juxtaposition with powerful enhancer elements associated with immunoglobulin heavy chain locus, which results in elevated levels of Bcl-2 mRNA and protein. Overexpression of Bcl-2 was also observed in a wide range of haematologic malignancies in the absence of $\mathrm{t}(14 ; 18)$ translocation, however, the exact cause of high levels of $\mathrm{Bcl}-2$ protein is not known. It is expected that altered expression or function of transcription factors (e.g. WT1) controlling the promoter region of $\mathrm{Bcl}-2$ gene might contribute to elevated levels of Bcl-2 protein (Campos et al. 1993). Elevated expression of $\mathrm{Bcl}-2$ has also been shown to be responsible for resistance of P-glycoprotein (P-gp) overexpressing L1210 cells to cisplatin without any contribution from the drug efflux activity of P-gp (Gibalová et al. 2009).

Several studies suggested that elevated levels of Bcl-2 protein may be associated with adverse clinical outcome (reduce rate of complete remission, shorter disease free or overall survival) as well as with more aggressive malignant phenotype and/or resistance to different classes of chemotherapeutic agents (Campos et al. 1993; Nuessler et al. 1999; Andreef and Konopleva 2002). Although high levels of Bcl-2 are commonly found at the diagnosis of disease, increased levels of Bcl-2 were not observed during relapse of acute leukaemia (Wuchter et al. 2000). However, some researchers observed no relation between levels of $\mathrm{Bcl}-2$ and response of AML or ALL patients to initial therapy. The differences in measured levels of Bcl-2 and its different prognostic significance may arise as a result of inclusion of non-homogenous groups of patients, in which predominate younger patients with favourable types of leukaemia, as well as of significant differences in Bcl-2 levels between individual samples. Another reason for the differences may be complex interactions between proteins of Bcl-2 family, which highlights the need for a comprehensive study of Bcl-2 family proteins (Kaufmann et al. 1998). It has been suggested that the BAX/
$\mathrm{Bcl}-2$ ratio may be a good prognostic factor in AML. Higher $\mathrm{BAX} / \mathrm{Bcl}-2$ ratio correlated significantly with a higher complete remission rate, longer overall and disease-free survival (Del Poeta et al.2003).

In addition to $\mathrm{Bcl}-2$, increased expression of $\mathrm{Bcl}-\mathrm{xl}$ is often observed in AML blasts. Previous studies suggest that increased expression of $\mathrm{Bcl}-\mathrm{xl}$ mediates resistance to a variety of treatments and drugs, including etoposide, doxorubicin, cisplatin, vincristine, bleomycine, paclitaxel and ionizing radiation (Datta et al. 1995; Minn et al. 1995). In case of ALL, elevated Bcl-xl may explain relative resistance of ALL cells to p53-dependent apoptosis (Račay et al.2008). Prognosis of patients with AML might also be influenced by Bcl-xl/Bcl$\mathrm{xs}$ ratio. It was reported that ratio of antiapoptotic $\mathrm{Bcl}-\mathrm{xl}$ to proapoptotic Bcl-xs is higher in chemoresistant cells (Ray et al. 1996; Yamaguchi et al. 2002).

The analysis of MCL1 protein expression in AML showed great heterogeneity, but no correlation was found between protein levels and response to standard chemotherapy. However, it was observed a two-fold increase of MCL1 levels at the time of leukaemic relapse (Kaufmann et al. 1998).

\section{Leukaemia therapy targeted to Bcl-2 family of proteins}

Since, high levels of antiapoptotic Bcl-2 family proteins are associated with resistance to chemo- or radiotherapy due to blocking of the mitochondrial pathway of apoptosis, currently targeted strategies that overcome the cytoprotective effects of $\mathrm{Bcl}-2$ and its related proteins have a leading position in development of new therapeutic options for acute leukaemia (Galluzzi et al. 2006). The options to avoid unwanted influence of antiapoptotic $\mathrm{Bcl}-2$ proteins include: inhibition of gene transcription, induction of mRNA degradation or the direct attack of proteins by inhibitors (Reed and Pellecchia 2005).

\section{Drugs regulating gene expression}

Several types of drugs altering the expression of antiapoptotic $\mathrm{Bcl}-2$ family genes were identified. Some synthetic retinoids reduce levels of $\mathrm{Bcl}-2$ or $\mathrm{Bcl}-\mathrm{xl}$ mRNA in leukaemia cells (e.g. fenretinide) (Reed 1999; Faderl et al. 2003). Inhibitors of histone deacetylases (HDACs), chromatin-modifying enzymes, have also the ability to decrease the expression of $B c l-2, B c l-x l$ or MCL1 at transcriptional level. Sodium butyrate is HDAC inhibitor that induces apoptotic cell death which is accompanied by up-regulation of proapoptotic BAX and down-regulation of antiapoptotic $\mathrm{Bcl}-2$ and $\mathrm{Bcl}-\mathrm{xl}$ (Choi 2006). Clinical trials of HDAC inhibitors are in progress, with hints of activity documented for lymphoma and some solid tumours (Kelly et al. 2003). The use of valproic acid, another HDAC inhibitor, has shown promising results in AML and 
myelodysplastic syndrome patients. Testing of effectiveness of valproic acid in other haematologic malignancies as well as optimalisation of treatment schedules may provide valuable and essential knowledge for its clinical application (Kuendgen and Gattermann 2007).

\section{Drugs attacking $m R N A$}

The effort to avoid the influence of antiapoptotic proteins of Bcl-2 family has led to attempts to reduce the levels of their mRNA using antisense oligonucleotides, short sequences of single-stranded synthetic deoxyribonucleotides that bind to specific complementary coding regions on mRNA. Formed RNA-DNA heteroduplex is a substrate for RNase-H, which cleave the target mRNA and prevent its processing and subsequent protein synthesis (Moreira et al. 2006). The specificity of this approach lies in the fact that each DNA sequence longer than 17 nucleotides occurs only once within human genome. Oblimersen sodium (Genasense; G3139), an 18-mer phosphorotioated oligodeoxynucleotide, binds to the first six codons of open reading frame of $\mathrm{Bcl}-2$ and such downregulates its expression (Klasa et al. 2002). Phase I and II of clinical trials of oblimersen alone and in combination with standard chemotherapy have shown encouraging results in chronic lymphoblastic leukaemia (CLL), non-Hodgkin lymphoma (NHL) and AML patients (Marcucci et al. 2005; Rom et al. 2009). Phase III of clinical trials in CLL patients has been already completed and significantly higher percentage of patients who achieved complete or partial remission of the disease compared to patients treated with chemotherapy alone was observed (O'Brien et al. 2009a). The combination of oblimersen with conventional first-line therapy based on cytarabine/anthacycline yielded a $48 \%$ rate of complete remission of de novo AML (Marcucci et al. 2005). Unfortunately, a randomized phase III trials of older AML patients failed to show improved outcomes for those receiving the combination with oblimersen (Marcucci et al. 2007).

\section{Small-molecule inhibitors of the Bcl-2 family of proteins}

The observation that antiapoptotic proteins of Bcl-2 family bind $\mathrm{BH} 3$ domains of proapoptotic proteins in a hydrophobic groove as a mean to suppress apoptosis initiation revealed the opportunity for the design of small molecules that bind directly into groove, thereby promoting apoptosis. Since these designed molecules mimic the function of "BH-3 only" proteins, they are termed $\mathrm{BH} 3$ mimetics. $\mathrm{BH} 3$ mimetics, destroying cancer cells by targeting specific pathways that allow survival of cancer cells, have been tested in clinical trials to improve therapy of malignant diseases including acute leukaemia (Zhang et al. 2007). The main advantage of these molecules is that they are highly permeable through membranes due to their low molecular weight. Until now, it was discovered more than ten substances that may prevent the interaction between $\mathrm{Bcl}-2$ or $\mathrm{Bcl}-\mathrm{xl}$ and proapoptotic proteins (Fig. 2). Currently, the most studied ABT-737 binds with high affinity $(\mathrm{Ki} \leq 1 \mathrm{nM})$ to the $\mathrm{BH} 3$ binding pocket of Bcl-2, Bcl-xl and Bcl-w, but not to MCL1 (Ki >1 $\mu \mathrm{M})$, similarly to the "BH-3 only" protein Bad (Oltersdorf et al. 2005). ABT-737 does not directly activate BAX or BAK, but binds to the antiapoptotic proteins and such prevents them to block apoptosis. ABT-737 exhibits single agent activity against a panel of haematological malignancies, especially in those that critically dependent on antiapoptotic Bcl-2 proteins for survival (Oltersdorf et al. 2005; Konopleva et al. 2006; Del Gaizo Moore et al. 2008; Vogler et al. 2008). Simultaneously, ABT-737 displays synergism with chemoand radiotherapy. It was observed 2-4-fold reduction of the median effective concentration $\left(\mathrm{EC}_{50}\right)$ of etoposide, doxorubicin, cisplatin and paclitaxel in the presence of ABT737 in a variety of cell lines (Oltersdorf et al. 2005). Since ABT-737 does not bind to MCL1, high levels of MCL1 may contribute to the development of resistance to this agent. Several reports have demonstrated that MCL1 represents a key determinant of ABT-737 sensitivity and resistance of cancer cells (van Delft et al. 2006; Chen et al. 2007; Kang et al. 2008; Chen et al. 2009). Downregulation of MCL1 by CDK inhibitors (e. g. roscovitine, flavopiridol, seliciclib) or Raf/Mek inhibitors (sorafenib) may dramatically increase ABT-737 cytotoxicity in malignant cells (Chen et al. 2007; Hikita et al. 2010; Yecies et al. 2010). Poor pharmaceutical properties (low solubility in water) of ABT-737 considerably limit its use as therapeutic agent. The second-generation inhibitor ABT-263, that is orally bioavailable, is currently in phase I clinical trials (Tse et al. 2008).

The efficacy of ABT-737 can also be increased by using its combination with obatoclax mesylate. Obatoclax (GX15-070) mesylate is besides $\mathrm{Bcl}-2, \mathrm{Bcl}-\mathrm{xl}$ and $\mathrm{Bcl}-\mathrm{w}$ capable to prevent MCL1/BAK binding (Nguyen et al. 2007). Phase I studies focused on haematological malignancies demonstrated biological activity, evidence for single-agent activity and good tolerability. Clinical response to obatoclax mesylate was observed in AML (Schimmer et al. 2008) and CLL patients (O'Brien et al. 2009b). In addition, recent study showed that the combination of HDAC inhibitors and obatoclax has synergistic antileukaemic activity mediated by induction of both apoptosis and autophagy (Wei et al. 2010).

Antimycin A and gossypol are the most promising from a number of natural compounds that have potential to inhibit antiapoptotic proteins of $\mathrm{Bcl}-2$ family. Antimycin A, a streptomyces-derived inhibitor of ubichinol-cytochrome $c$ reductase of the mitochondrial respiration chain, promotes cell death by binding to Bcl-2 (Tzung et al. 2001). Gossypol, capable to bind in submicromolar concentrations to Bcl-2 and MCL1, exhibits anticancer effects in vitro in different 
<smiles>COC1=CC(c2cc3ccccc3[nH]2)=N/C1=C\c1[nH]c(C)cc1C</smiles>

GX 015-070<smiles>Cc1cc2c(C(C)C)c(O)c(O)c(C=O)c2c(O)c1-c1c(C)cc2c(C(C)C)c(O)c(O)c(C=O)c2c1O</smiles>

Gossypol

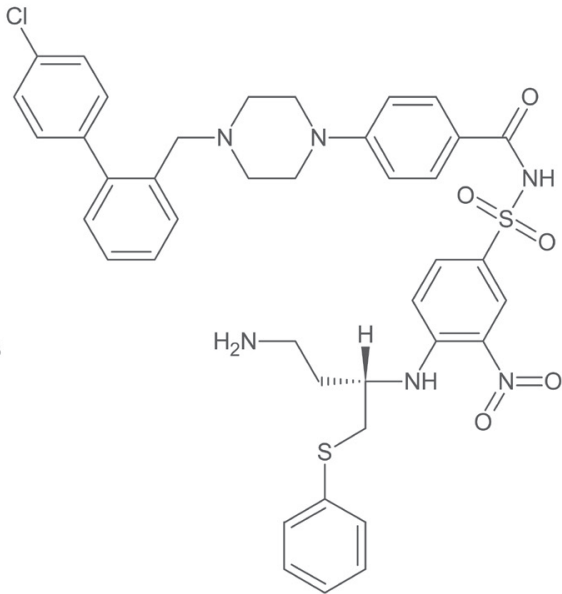

ABT-737<smiles>CC1(C)CCC(c2ccc(Cl)cc2)=C(CN2CCN(c3ccc(C(=O)NS(=O)(=O)c4ccc(N[C@H](CCN5CCOCC5)CSc5ccccc5)c(S(=O)(=O)C(F)(F)F)c4)cc3)CC2)C1</smiles>

ABT-263(16)

Figure 2. The structures of small-molecule inhibitors of $\mathrm{Bcl}-2$ and $\mathrm{Bcl}-\mathrm{xl}$ (BH3 mimetics).

cancer cell lines (Oliver et al. 2004). However, clinical use of gossypol is significantly limited by its gastrointestinal toxicity (Kang and Reynolds 2009).

Due to complex interaction between $\mathrm{Bcl}-2$ proteins, it is likely that efficient recovery of sensitivity of malignant cells to apoptosis may require the use of combination of drugs targeting several antiapoptotic proteins. For such reason, recent research is directed at identification of new small molecules that could make stable complexes simultaneously with Bcl-2, Bcl-xl and MCL1. A few new designed molecules are waiting for evaluation of clinical efficiency (Dalafave and Prisco 2010).

\section{Conclusions}

Acute leukaemia is aggressive haematologic malignancy, which arise as a consequence of malignant transformation of 
haematopoietic cells at early stage of differentiation. Despite of improvements in treatment strategies, prognosis of acute leukaemia is still poor. Efficacy of current approaches to cure leukaemia, including chemo-, radio- and immunotherapy critically depends mainly on the proper functioning of cell death programs. Therefore, deregulation of apoptosis is often associated with disease progression and resistance to chemotherapy. Recently, much attention is paid to investigate the options to restore the sensitivity of leukaemic cells, as well as the possible ways to increase the efficiency of chemotherapeutic treatment. Since the effects of chemotherapy are not strictly specific to tumour cells, but they are more or less toxic to normal cells as well, new targeted therapies could simultaneously help to alleviate the side effects of chemotherapy. Detailed study of the molecular mechanisms of apoptosis has helped to identify several potential targets for developing new drugs. These are particularly the proteins that block apoptosis, which increased expression is often observed in malignant cells and is associated with worse prognosis of disease and resistance to chemotherapy.

More detailed research of the link between apoptosis deregulation and cancer development as well as translation of acquired knowledge into clinical practice may lead in the future to fundamental changes in prognosis of acute leukaemia patients.

Acknowledgment. This work was supported by APVV VVCE 0064-07 Biomembranes. Authors are grateful to Pavol Kupec for his excellent help with figures. J. J., J. H., A. S., D. D. and P. R. have no conflict of interest and no financial interest in the publication of this manuscript.

\section{References}

Aldridge D. R., Radford I. R. (1998): Explaining differences in sensitivity to killing by ionizing radiation between human lymphoid cell lines. Cancer Res. 58, 2817-2824

Andreef M., Konopleva M. (2002): Mechanisms of drug resistance in AML. Cancer Treat. Res. 112, 237-262

Campos L., Rouault J.-P., Sabido O., Oriol P., Roubi N., Vasselon Ch., Archimbaud E., Magaud J.-P., Guyotat D. (1993): High expression of bcl-2 protein in acute myeloid leukemia cells is associated with poor response to chemotherapy. Blood 81, 3091-3096

Chen S., Dai Y., Harada H., Dent P., Grant S. (2007): MCL1 downregulation potentiates ABT-737 lethality by cooperatively inducing BAK activation and BAX translocation. Cancer Res. 67, 782-791 doi:10.1158/0008-5472.CAN-06-3964

Chen S., Dai Y., Pei X.-Y., Grant S. (2009): Bim upregulation by histone deacetylase inhibitors mediates interactions with the Bcl-2 antagonist ABT-737: evidence for distinct roles for Bcl-2, Bcl-xL and MCL1. Mol. Cell. Biol. 29, 6149-6169 doi:10.1128/MCB.01481-08
Chipuk J. E., Fisher J. C., Dillon Ch. P., Kriwacki R. W., Kuwana T. (2008): Mechanism of apoptotic induction by inhibition of the anti-apoptotic BCL-2 proteins. Proc. Natl. Acad. Sci. USA 105, 20327-20332 doi:10.1073/pnas.0808036105

Chipuk J. E., Kuwana T., Bouchier-Hayes L., Droin N. M., Schuler M., Green D. R. (2004): Direct activation of BAX by p53 mediates mitochondrial membrane permeabilization and apoptosis. Science 303, 1010-1014

doi:10.1126/science.1092734

Choi Y. H. (2006): Apoptosis of U937 human leukemic cells by sodium butyrate is associated with inhibition of telomerase activity. Int. J. Oncol. 29, 1207-1213

Dalafave D. S., Prisco G. (2010): Inhibition of antiapoptotic BCLXL, BCL-2 and MCL1 proteins by small molecule mimetics. Cancer Inform. 9, 169-177 doi: $10.4137 / C I N . S 5065$

Datta R., Manome Y., Taneja N., Boise L. H., Weichselbaum R., Thompson C. B., Slapak C. A., Kufe D. (1995): Overexpression of $\mathrm{Bcl}-\mathrm{xL}$ by cytotoxic drug confers resistance to ionizing radiation-induced internucleosomal DNA fragmentation. Cell Growth Diff. 6, 363-370

Del Gaizo Moore V., Schlis K. D., Sallan S. E., Armstrong S. A., Letai A. (2008): BCL-2 dependence and ABT-737 sensitivity in acute lymphoblastic leukemia. Blood 111, 2300-2309 doi:10.1182/blood-2007-06-098012

Del Poeta G., Venditti A., Del Principe M. I., Maurillo L., Buccisano F., Tamburini A., Cox M. Ch., Franchi A., Bruno A., Mazzone C., Panetta P., Suppo G., Masi M., Amadori S. (2003): Amount of spontaneous apoptosis detected by BAX/Bcl-2 ratio predicts outcome in acute myeloid leukemia (AML). Blood 101, 2125-2131 doi:10.1182/blood-2002-06-1714

Elmore S. (2007): Apoptosis: A review of programmed cell death. Toxicol. Pathol. 35, 495-516 doi:10.1080/01926230701320337

Faderl S., Lotan R. Kantarjian H. M., Harris S., Van Q., Estrov Z. (2003): N-(4-hydroxyphenyl)retinamide (fenretinide, 4-HPR), a retinoid compound with antileukemic and proapoptotic activity in acute lymphoblastic leukemia (ALL). Leuk. Res. 27, 259-266 doi:10.1016/S0145-2126(02)00162-5

Galluzzi L., Larochette N., Zamzami N., Kroemer G. (2006): Mitochondria as a therapeutic target for cancer chemotherapy. Oncogene 25, 4812-4830 doi:10.1038/sj.onc. 1209598

Gibalová L., Sedlák J., Labudová M., Barancík M., Reháková A., Breier A., Sulová Z. (2009): Multidrug resistant P-glycoprotein positive L1210/VCR cells are also cross-resistant to cisplatin via a mechanism distinct from P-glycoproteinmediated drug efflux activity. Gen. Physiol. Biophys. 28, 391-403 doi:10.4149/pb_2009_04_391

Haferlach C., Dicker F., Herholz H., Schnittger S., Kern W., Haferlach T. (2008): Mutations of the TP53 gene in acute myeloid leukemie are strongly associated with a complex aberrant karyotype. Leukemia 22, 1539-1541 doi:10.1038/leu.2008.143 
Hanahan D., Weinberg R. A. (2000): The hallmarks of cancer. Cell 100, 57-70 doi:10.1016/S0092-8674(00)81683-9

Haupt S., Berger M., Goldberg Z., Haupt Y. (2003): Apoptosis - the p53 network. J. Cell Sci. 116, 1077-4085 doi: $10.1242 /$ jcs. 00739

Hikita H., Takehara T., Shimizu S., Kodama T., Shigekawa M., Iwase K., Hosui A., Miyagi T., Tatsumi T., Ishida H., Li W., Kanto T., Hiramatsu N., Hayashi N. (2010): The Bcl-xL inhibitor, ABT-737, efficiently induces apoptosis and suppresses growth of hepatoma cells in combination with sorafenib. Hepatology 52, $1310-1321$ doi:10.1002/hep.23836

Jin Z., El-Deiry W. S. (2005): Overview of cell death signalig pathways. Cancer Biol. Ther. 4, 139-163 doi:10.4161/cbt.4.2.1508

Kang M. H., Reynolds P. (2009): Bcl-2 inhibitors: targeting mitochondrial apoptotic pathways in cancer therapy. Clin. Cancer Res. 15, 1126-1132 doi:10.1158/1078-0432.CCR-08-0144

Kang M. H., Wan Z., Kang Y. H., Sposto R., Reynolds C. P. (2008): Mechanism of synergy of N-(4-hydroxyphenyl)retinamide and ABT-737 in acute lymphoblastic leukemia cell lines: MCL1 inactivation. J. Natl. Cancer Inst. 100, 580-595 doi:10.1093/jnci/djn076

Kaufmann S. H., Karp J. E., Svingen P. A., Krajewski S., Burke P. J., Gore S. D., Reed J. C. (1998): Elevated expression of the antiapoptotic regulator MCL1 at the time of leukemic relapse. Blood 91, 991-1000

Kelly W. K., Richon V. M., O‘Connor O., Curley T., MacGregorCurtelli B., Tong W., Klang M., Schwartz L., Richardson S., Rosa E., Drobnjak M., Cordon-Cordo C., Chiao J. H., Rifkind R., Marks P. A., Scher H. (2003): Phase I clinical trial of histone deacetylases inhibitor: suberoylanilide hydroxamic acid administered intravenously. Clin. Cancer Res. 9, 3578-3588

Kerr J. F., Wyllie A. H., Currie A. R. (1972): Apoptosis: a basic phenomenon with wide-ranging implications in tissue kinetics. Br. J. Cancer 26, 239-257 doi:10.1038/bjc.1972.33

Kim H., Rafiuddin-Shah M., Tu H. Ch., Jeffers J. R., Zambett G. P., Hsieh J., Cheng E. (2006): Hierarchical regulation of mitochondrion-dependent apoptosis by BCL-2 subfamilies. Nat. Cell Biol. 8, 1348-1358 doi: $10.1038 /$ ncb 1499

Kitada S., Pedersen I. M., Schimmer A. D., Reed J. C. (2002): Dysregulation of apoptosis genes in hematopoietic malignancies. Oncogene 21, 3459-3474 doi: $10.1038 /$ sj.onc. 1205327

Klasa R. J., Gillum A. M., Klem R. E., Frankel S. R. (2002): Oblimersen $\mathrm{Bcl}-2$ antisense: Facilitating apoptosis in cancer treatment. Antisense Nucleic Acid Drug Dev. 12, 193-213 doi:10.1089/108729002760220798

Klobusická M., Kusenda J., Babusíkova O. (2001): Expression of p53 and bcl-2 proteins in acute leukemias: an immunocytochemical study. Neoplasma 48, 489-495

Konopleva M., Contractor R., Tsao T., Samudio I., Ruvolo P. P., Kitada S., Deng X., Zhai D., Shi Y.-X., Sneed T., Verhaegen
M., Soengas M., Ruvolo V. R., McQueen T., Schober W. D., Watt J. C., Jiffar T., Ling X., Marini F. C., Harris D., Dietrich M., Estrov Z., McCubrey J., May W. S., Reed J. C., Andreeff M. (2006): Mechanisms of apoptosis sensitivity and resistance to BH3 mimetic ABT-737 in acute myeloid leukemia. Cancer Cell 10, 375-388 doi:10.1016/j.ccr.2006.10.006

Konopleva M., Watt J., Contractor R., Tsao T., Harris D., Estrov Z., Bornmann W., Kantarjian H., Viallet J., Samudio I., Andreeff M. (2008): Mechanisms of antileukemic activity of the novel Bcl-2 homology domain-3 mimetic GX15-070 (obatoclax). Cancer Res. 68, 3413-3420 doi:10.1158/0008-5472.CAN-07-1919

Krug U., Ganser A., Koeffler H. P. (2002): Tumor suppressor genes in normal and malignant hematopoiesis. Oncogene 21, 3475-3495 doi:10.1038/sj.onc.1205322

Kuendgen A., Gattermann N. (2007): Valproic acid for the treatment of myeloid malignancies. Cancer 110, 943-954 doi:10.1002/cncr.22891

Letai A., Sorcinelli M. D., Beard C., Korsmeyer S. J. (2004): Antiapoptotic BCL-2 is required for maintenance of a model leukemia. Cancer Cell 6, 241-249 doi:10.1016/j.ccr.2004.07.011

Marcucci G. Moser B., Blum W., Stock M., Wetzler M., Kolitz J. E., Thakuri M., Carter T., Stuart R. K., Larson R. A. (2007): A phase III randomized trial of intensive induction and consolidation chemotherapy \pm oblimersen, a pro-apoptotic $\mathrm{Bcl}-2$ antisense oligonucleotide in untreated acute myeloid leukemia patients $>60$ years old. J. Clin. Oncol. (ASCO Annual Meeting Proceedings Part 1) 25, 7012

Marcucci G., Stock W., Dai G., Klisovic R. B., Liu S., Klisovic M. I., Blum W., Kefauver Ch., Sher D. A., Green M., Moran M., Maharry K., Novick S., Bloomfield C. D., Zwiebel J. A., Larson R. A., Grever M. R., Chan K. K., Byrd J. C. (2005): Phase I study of oblimersen sodium, an antisense to $\mathrm{Bcl}-2$, in untreated older patients with acute myeloid leukemia: pharmacokinetics, pharmacodynamics, and clinical acticity. J. Clin. Oncol. 23, 3404-3411 doi:10.1200/JCO.2005.09.118

Mareková M., Vávrová J., Vokurková D. (2003): Monitoring of premitotic and postmitotic apoptosis in gamma-irradiated HL-60 cells by the mitochondrial membrane protein-specific monoclonal antibody APO2.7. Gen. Physiol. Biophys. 22, 191-200

Mihara M., Erster S., Zaika A., Petrenko O., Chittenden T., Pancoska P., Moll U. M. (2003): p53 has a direct apoptogenic role in mitochondria. Moll. Cell 11, 577-590 doi:10.1016/S1097-2765(03)00050-9

Minn A. J., Rudin Ch. M., Boise L. H., Thompson C. B. (1995): Expression of Bcl-xL can confer a multidrug resistance phenotype. Blood 86, 1903-1910

Moreira J. N., Santos A., Simões S. (2006): Bcl-2-targeted antisense therapy (Oblimersen sodium): towards clinical reality. Rev. Recent Cli. Trials 1, 217-235 doi:10.2174/157488706778250050

Nahi H., Lehmann S., Bengtzen M., Jansson M., Mollgard L., Paul C., Merup M. (2008): Chromosomal aberrations in 17p 
predict in vitro drug resistance and short overall survival in acute myeloid leukemia. Leuk. Lymphoma 49, 508-516 doi:10.1080/10428190701861645

Nguyen M., Marcellus R. C., Roulston A., Watson M., Serfass L., Murthy Madiraju S. R., Goulet D., Viallet J., Bélec L., Billot X., Acoca S., Purisima E., Wiegmans A., Cluse L., Johnstone R. W., Beauparlant P., Shore G. C. (2007): Small molecule obatoclax (GX 15-070) antagonizes MCL1 and overcomes MCL1-mediated resistance to apoptosis. Proc. Natl. Acad. Sci. USA 104, 19512-19517

doi:10.1073/pnas.0709443104

Nuessler V., Stötzer O., Gullis E., Pelka-Fleisher R., Pogrebniak A., Gieseler F., Wilmanns W. (1999): Bcl-2, BAX, bcl-xL expression in human sensitive and resistant leukemia cell lines. Leukemia 13, 1864-1872 doi:10.1038/sj.leu.2401571

O'Brien S., Moore J. O., Boyd T. E., Larratt L. M., Skotnicki A. B., Koziner B., Chanan-Khan A. A., Seymour J. F., Gribben J., Itri L. M., Rai K. R., (2009a): 5-year survival in patients with relapsed or refractory chronic lymphocytic leukemia in a randomized, phase III trial of fludarabine plus cyclophosphamide with or without oblimersen. J. Clin. Oncol. 27, 5208-5212

O'Brien S. M., Claxton D. F., Crump M., Faderl S., Kipps T., Keating M. J., Viallet J., Cheson B. D. (2009b): Phase I study of obatoclax mesylate (GX15-070), a small molecule pan-Bcl-2 family antagonist, in patients with advanced chronic chronic lymphocytic leukemia. Blood 113, 299-305

doi:10.1182/blood-2008-02-137943

Oliver C. L., Bauer J. A., Wolker K. G., Ubell M. L., Narayan A. (2004): In vitro effect of the BH3 mimetic, (-)-gossypol, on head and neck squamous cell carcinoma cells. Clin. Cancer Res. 10, 7757-7763 doi:10.1158/1078-0432.CCR-04-0551

Oltersdorf T., Elmore S.W., Shoemaker A. R., Armstrong R. C., Augeri D. J., Belli B. A., Bruncko M., Deckwerth T. L., Dinges J., Hajduk P. J., Joseph M. K., Kitada S., Korsmeyer J., Kunzer A. R., Letai A., Li Ch., Mitten M. J., Nettesheim D. G., Ng S., Nimmer P. M., O'Connor J. M., Oleksijew A., Petros A. M., Reed J. C., Shen W., Tahir S. K., Thompson C. B., Tomaselli K. J., Wang B., Wendt M. D., Zhang H., Fesik S. W., Rosenberg S. H. (2005): An inhibitor of Bcl-2 family proteins induces regression of solid tumours. Nature 435, 677-681 doi:10.1038/nature03579

Polster B. M., Fiskum G. (2004): Mitochondrial mechanisms of neural cell apoptosis. J. Neurochem. 90, 1281-1289 doi:10.1111/j.1471-4159.2004.02572.x

Račay P., Hatok J., Hudeček J., Chudej J., Jurečeková J., Dobrota D. (2008): Transcription of genes of p53-dependent apoptosis in acute leukemia. Int. J. Mol. Med. 22, 833-839

Ray S., Bullock G., Nunez G., Tang C., Ibrado A. M., Huang Y., Bhalla K. (1996): Enforced expression os Bcl-xS induces differenciation and sensitizes chronic myelogenous leukemia-blast crisis K562 cells to 1-beta-D-arabinofuranosylcytosine-mediated differenciation and apoptosis. Cell Growth Differ. 7, 1617-1623

Reed J. (1999): Fenretinide: the death of a tumor cell. J. Natl. Cancer Inst. 91, 1099-1100 doi:10.1093/jnci/91.13.1099
Reed J. C., Pellecchia M. (2005): Apoptosis-based therapies for hematologic malignancies. Blood 106, 408-418 doi:10.1182/blood-2004-07-2761

Rom J. von Minckwitz G., Marmé F., Ataseven B., Kozian D., Sievert M., Schlehe B., Schuetz F., Scharf A., Kaufmann M., Sohn C., Schneeweiss A. (2009): Phase I study of apoptosis gene modulation with oblimersen within preoperative chemotherapy in patients with primary breast cancer. Ann. Oncol. 20, 1829-1835 doi:10.1093/annonc/mdp208

Sax J. K., El Deiry W. S. (2003): p53 downstream targets and chemosensitivity. Cell Death Differ. 10, 413-417 doi:10.1038/sj.cdd.4401227

Schimmer A. D., O'Brien S., Kantarjian H., Brandwein J., Cheson B. D., Minden M. D., Yee K., Ravandi F., Giles F., Schuh A., Gupta V., Andreeff M., Koller Ch., Chang H., Kamel-Reid S., Berger M., Viallet J., Borthakur G. (2008): A phase I study of the pan Bcl-2 family inhibitor obatoclax mesylate in patients with advances hematologic malignancies. Clin. Cancer Res. 14, 8295-8301 doi:10.1158/1078-0432.CCR-08-0999

Schuler D., Szende B. (2004): Apoptosis in acute leukemia. Leukemia Research 28, 661-666 doi:10.1016/j.leukres.2003.10.032

Schultz D. R., Harrington W. J. (2003): Apoptosis: Programmed cell death at a molecular level. Semin. Arthritis Rheum. 32, 345-369 doi:10.1053/sarh.2003.50005

Soussi T. (2007): p53 alterations in human cancers: more questions than answers. Oncogene 26, 2145-2156 doi: $10.1038 /$ sj.onc. 1210280

Strasser A. (2005): The role of BH3-only proteins in the immune system. Nat. Rev. Immunol. 5, 189-200 doi:10.1038/nri1568

Taylor K., Micha D., Ranson M., Dive C. (2006): Recent advances in targeting regulators of apoptosis in cancer cells for therapeutical gain. Expert Opi. Investig. Drugs 15, 669-690 doi:10.1517/13543784.15.6.669

Testa U., Riccioni R. (2007): Deregulation of apoptosis in acute myeloid leukemia. Haematologica 92, 81-94 doi:10.3324/haematol.10279

Tse Ch., Shoemaker A. R., Adickes J., Anderson M. G., Chen J., Jin S., Johnson F., Marsh K. C., Mitten M. J., Nimmer P., Roberts L., Tahir S. K., Xiao Y., Yang X., Zhang H., Fesik S., Rosenberg S. H., Elmore S. W. (2008): ABT-263: a potent and orally bioavailable Bcl-2 family inhibitor. Cancer Res. 68, 3421-3428 doi:10.1158/0008-5472.CAN-07-5836

Tsujimoto Y., Cossman J., Jaffe E., Croce C. M. (1985): Involvement of the bcl-2 gene in human follicular lymphoma. Science 228, $1440-1443$ doi:10.1126/science. 3874430

Tzung S. P., Kim K. M., Basanez G., Giedt C. D., Simon J., Zimmerberg J., Zhang K. Y., Hockenbery D. M. (2001): Antimycin A mimics a cell-death-inducing Bcl-2 homology domain 3. Nat. Cell Biol. 3, 183-191

doi:10.1038/35055095

van Delft M. F., Huang D. C. (2006): How the Bcl-2 family of proteins interact to regulate apoptosis. Cell Res. 16, 203-213 doi:10.1038/sj.cr.7310028

van Delft M. F., Wei A. H., Mason K. D., Vanderberg C. J., Chen L., Czabotar P. E., Willis S. N., Scott C. L., Day C. L., Cory S., 
Adams J. M., Roberts A. W., Huang D. C. S. (2006): The BH3 mimetic ABT- 737 targets selective Bcl-2 proteins and efficiently induces apoptosis via BAK/BAX if MCL1 is neutralized. Cancer Cell 10, 389-399

doi:10.1016/j.ccr.2006.08.027

Vogler M., Dinsdale D., Sun X. M., Young K. W., Butterworth M., Nicotera P., Dyer M. J. S., Cohen G. M. (2008): A novel paradigm for rapid ABT-737-induced apoptosis involving outer mitochondrial membrane rupture in primary leukemia and lymphoma cells. Cell Death Differ. 15, 820-830 doi:10.1038/cdd.2008.25

Wei Y., Kadia T., Tong W., Zhang M., Jia Y., Yang H., Hu Y., Tambaro F. P., Viallet J., O'Brien S., Garcia-Manero G. (2010): The combination of a histone deacetylase inhibitor with the Bcl-2 homology domain-3 mimetic GX15-070 has synergistic antileukemia activity by activating both apoptosis and autophagy. Clin. Cancer Res. 16, 3923-3932 doi:10.1158/1078-0432.CCR-10-0032

Willis S. N., Chen L., Dewson G., Wei A., Naik E., Fletcher J. I., Adams J. M., Huang D. C. S. (2005): Proapoptotic BAK is sequestered by MCL1 and Bcl-xL, but not Bcl-2, until displaced by BH3-only proteins. Genes Development 19, 1294-1305 doi:10.1101/gad.1304105

Wong W. W., Puthalakath H. (2008): Bcl-2 family proteins: the sentinels of the mitochondrial pathway. IUBMB Life 60, 390-397 doi:10.1002/iub.51

Wu Y., Mehew J. W., Heckman C. A., Arcinas M., Boxer L. M. (2001): Negative regulation of bcl-2 expression by p53 in hematopoietic cells. Oncogene 20, 240-251 doi:10.1038/sj.onc.1204067

Wuchter C., Karawajew L., Ruppert V., Schrappe M., Harbott J., Ratei R., Dorken B., Ludwig W. D. (2000): Constitutive expression levels of CD95 and Bcl-2 as well as CD95 function and spontaneous apoptosis in vitro do not predict the response to induction chemotherapy and relapse rate in childhood acute lymphoblastic leukemia. Br. J. Haematol. 110, 154-160 doi:10.1046/j.1365-2141.2000.02147.x

Yamaguchi H., Inokuchi K., Dan K. (2002): The study for loss of bcl$\mathrm{xs}$ expression as a prognostic factor in acute myeloid leukemia. Leuk. Res. 26, 1119-1123 doi:10.1016/S0145-2126(02)00061-9

Yecies D., Carlson N. E., Deng J., Letai A. (2010): Acquired resistance to ABT-737 in lymphoma cells that up-regulate MCL1 and BFL-1. Blood 115, 3304-3313 doi:10.1182/blood-2009-07-233304

Youle R. J., Strasser A. (2008): The BCL-2 family proteins: oposite activities that mediate cell death. Nat. Rev. Mol. Cell Biol. 9, 47-59 doi:10.1038/nrm2308

Zhang L., Ming L., Yu J. (2007): BH3 mimetics to improve cancer therapy; mechanisms and examples. Drug Resist. Updat. 10, 207-217

doi:10.1016/j.drup.2007.08.002

Received: December 6, 2010

Final version accepted: January 20, 2011 